F. Reprod. Fert. (1967) 14, 143-145

BRIEF COMMUNICATION

\title{
FERTILITY IN A MAN AUTO-IMMUNIZED TO SPERMATOZOA
}

\author{
BO FJÄLLBRANT \\ Department of Bacteriology, University of Göteborg, and \\ The Clinic of Obstetrics and Gynaecology II, \\ Sahlgren Hospital, Göteborg, Sweden
}

(Received 4th January 1967)

\begin{abstract}
Summary. A 43-year-old man was in his second barren marriage when he became father of a normal child despite rather high sperm agglutinin titres of his serum for 2 years before and 1 year after the conception. The blood groups and $\mathrm{Rh}$ genotypes of the husband, the wife and the child do not challenge the paternity of the husband.
\end{abstract}

When the occurrence of sperm agglutination due to antibodies was first observed in man, the condition was considered to be a cause of sterility (Wilson, 1954, 1956). Rümke \& Hellinga (1959) found that fertile men also sometimes have sperm agglutinins but in low titres, lower than $1: 32$, as determined by the method of Kibrick, Belding \& Merrill (1952). Fertility in three men with still higher sperm agglutinin titres, $1: 80$ and 1:320, was reported by Phadke \& Padukone (1964). In these cases no detailed examinations were reported and no proof of the paternities was set forth. In the case reported below these desiderata are fulfilled. This man was earlier described as a case of sterility in a paper about immunoagglutination of sperm (Fjällbrant, 1965).

At the time of writing the patient is 44 years old. He married for the first time in 1943. The marriage was infertile and ended in divorce after 7 years. His former wife re-married and immediately became pregnant. In 1954 the patient re-married. This marriage also proved to be childless. A sterility investigation of the couple was performed at our clinic from 1958 to 1963. No cause of infertility was found in the wife. At the beginning of the clinical investigation the seminal findings were recorded as normal quantitatively and qualitatively, but at this time spontaneous agglutination of spermatozoa was not known to have significance. In repeated post-coital tests an obviously reduced sperm penetration was noted. Only a few spermatozoa were found in the cervix and not a single spermatozoon in the uterine cavity. Therefore, several homologous inseminations were done, but in vain. In 1963, a heavy spontaneous sperm agglutination was observed during another seminal investigation. The agglutination type was tail-to-tail. A sperm agglutinin test of the husband's serum was positive at a titre of $1: 1024$, determined by Kibrick's method. The sperm 
immobilizing activity of the inactivated serum was also high, for $90 \%$ of normal, fresh spermatozoa were immobilized within $3 \mathrm{hr} 10 \mathrm{~min}$ in the presence of fresh guinea-pig serum. A control serum had no immobilizing effect within this time.

Earlier, the patient had suffered symptoms of cystitis twice with a long interval between, the first time during his first marriage. Examination of testes, penis and prostate showed normal findings.

In December 1964, the sperm agglutinin titre was 1:128, a semen sample showed strong agglutination and the in-vitro cervical mucus invasion test showed a very poor penetration ability.

His wife became pregnant in July 1965. As soon as the pregnancy was known, in August, the husband was examined once more. The sperm agglutinin titre was still $1: 128$. The semen sample had a high leucocyte count, but the typical tail-to-tail agglutination was still discernible. The penetration ability of the spermatozoa seemed to be better but was still clearly reduced. A urological investigation revealed a prostato-vesiculitis. This was treated, but despite

\section{TABLE 1}

CLASSIFICATION OF THE BLOOD GROUPS OF THE HUSBAND, WIFE AND GHILD

\begin{tabular}{|c|c|c|c|c|c|c|c|c|c|c|c|c|}
\hline & \multicolumn{2}{|c|}{$A B O$} & \multicolumn{6}{|c|}{$R h$} & \multicolumn{2}{|c|}{$M \mathcal{N}$} & \multirow{2}{*}{$\frac{\text { Kell }}{\text { Anti- }}$} & \multirow{2}{*}{$\frac{\text { Duffy }}{\text { Anti- }^{F^{a}}}$} \\
\hline & $\underset{A}{A n t i-}$ & $\underset{B}{A n t i-}$ & $\stackrel{\text { Anti- }}{C+C^{w}}$ & $\underset{C^{w}}{\text { Anti- }}$ & $\stackrel{\text { Anti- }}{D}$ & $\underset{E}{A n t i-}$ & $\underset{c}{A n t i-}$ & $\underset{e}{A n t i-}$ & $\stackrel{A n t i-}{M}$ & $\mathcal{N}_{\mathcal{N}}^{A n-}$ & & \\
\hline $\begin{array}{l}\text { Husband } \\
\text { Wife } \\
\text { Child }\end{array}$ & $\bar{t}$ & $\begin{array}{l}- \\
-\end{array}$ & $\begin{array}{l}+ \\
+ \\
+\end{array}$ & $\begin{array}{l}- \\
-\end{array}$ & $\frac{t}{t}$ & $\begin{array}{l}- \\
- \\
-\end{array}$ & $\underline{+}$ & $\begin{array}{l}+ \\
+ \\
+\end{array}$ & $\begin{array}{l}+ \\
+ \\
+\end{array}$ & $\underline{+}$ & $\bar{z}$ & $\begin{array}{l}+ \\
+ \\
+\end{array}$ \\
\hline
\end{tabular}

treatment, symptoms of active prostato-vesiculitis remained a year after the beginning of the treatment. The agglutinin titre was $1: 256$ in May 1966.

The pregnancy was quite normal. A normal boy was born at term without complications.

The results of testing the red blood cells of husband, wife and child with different blood-group antisera are given in Table 1.

Some correlation between the sperm agglutinin titre and the penetration ability of spermatozoa in cases of immunoagglutination has been reported (Fjällbrant, 1965). In the present case sperm agglutinin titres between 1:128 and 1:1024 were found during the 2 years before the conception and titres up to $1: 256$ about 1 year after the conception. The penetration ability of the spermatozoa was consistently reduced. It is unlikely that a critical change of the degree of immunization was the cause of the conception. The role of the prostato-vesiculitis is obscure. It seems plausible that, besides the agglutination, the reduction of the penetration ability of the spermatozoa is the main cause of sterility in cases of auto-immunization to spermatozoa. The present case suggests that this obstacle may be overcome, e.g. under ideal conditions in regard to the passive sperm transport. If it is so, the therapeutic possibilities would be good. 


\section{REFERENCES}

FJällbrant, B. (1965) Immunoagglutination of sperm in cases of sterility. Acta obstet. gynec. scand. 44, 474.

Kibrick, S., Belding, D. L. \& Merrill, B. (1952) Methods for the detection of antibodies against mammalian spermatozoa. II. A gelatin agglutination test. Fert. Steril. 3, 430.

Phadke, A. M. \& Padukone, K. (1964) Presence and significance of autoantibodies against spermatozoa in the blood of men with obstructed vas deferens. F. Reprod. Fert. 7, 163.

Rümke, P. \& Hellinga, G. (1959) Antibodies against spermatozoa in sterile men. Am. F. clin. Path. 32, 357.

Wirson, L. (1954) Sperm agglutinins in human semen and blood. Proc. Soc. exp. Biol. Med. 85, 652.

Wirson, L. (1956) Sperm agglutination due to autoantibodies. A new cause of sterility. Fert. Steril. 7, 262. 